УДК 338.45

DOI: https://doi.org/10.26642/ema-2019-3(89)-47-56

В.В. Смачило, к.е.н., доц.

Т.Л. Наливайко, здобувач

Харківський національний університет будівництвва та архітектури

\title{
Ідентифікація соціально-економічної категорії «персонал підприємства»
}

Дослідження ролі людини в процесі праџуі завжди було важливим науковим завданням і його актуальність не втрачається через те, шуо сучасні умови реалізації трудового прочесу постійно знаходяться в динамічній трансформації. Отже, вивчення сутнісного навантаження категорій, які характеризують людину в процесі праці, й на сьогоднішньому етапі є актуальним. Однією з найбільш популярних категорій, які широко застосовуються як в економічній, так $і$ науковій сфері, $\epsilon$ «персонал». Незважаючи на широке використання категорії «персонал», в науковому та економічному обігу, відсутня ї̈ чітка ідентифікація та неузгодженість із нормативно-правовим полем України в сфері праџі, щуо не дозволяє коректно використовувати цее поняття в соціальноекономічних дослідженнях.

Відповідно, метою дослідження є ідентифікація соиіально-економічної категорії «персонал підприємства» із врахуванням термінології нормативно-правової бази України.

У статті авторами проаналізовано термінологію стосовно людини в сфері праці та узгоджено із нормативно-правовим забезпеченням Украӥни.

Проведене дослідження дозволяє представити авторське бачення персоналу: ие фізичні особи, які мають трудові взаємовідносини із роботодавием на основі трудового договору/контракту, тобто це всі працівники роботодавця з точки зору тлумачення працівника як такого.

Із врахуванням особливостей господарської діяльності підприємств в Украӥні (фізичні особироботодавиі не ведуть звітність щодо облікової кількості штатних працівників, а підприємства є юридичними особами), персонал підприємства - це сукупність фізичних осіб, які мають трудові взаємовідносини із роботодавцем на основі трудового договору/контракту та кількісно являють собою суму облікової кількості штатних працівників підприємства та зовнішніх сумісників.

Ключові слова: працівник; персонал; роботодавец̧ь; персонал підприємства.

Актуальність теми. Сучасні трансформації соціально-економічних систем, які відбуваються за принципами експоненціального розвитку, свідчать про зростаючу роль людини у всіх сферах життєдіяльності. Саме тому управління людиною в процесі праці, яка має різноманітну ідентифікацію залежно від етапу, місця та мети управління, і визначення ії сутнісного навантаження на сучасному етапі, набуває актуальної ролі.

Аналіз останніх досліджень та публікації, на які спирається автор. Вивчення персоналу як об'єкта управління широко представлене як в навчальній, так і науковій літературі. Серед дослідників вказаного питання можна виокремити авторів навчальної літератури в сфері економіки та управління персоналом: В.Г. Никифоренко, Є.П. Качан, Г.О. Швиданенко, В.Г. Андрійчук, О.А. Грішнова, А.В. Шегда та наукових публікацій: Р.Д. Якубів, Д.І. Шолубко, Г.Ю. Ткачук, В.В. Савіцький, М.І. Русінко Питання, що розглядалися авторами, присвячені як загальним положенням управління персоналом, економіки праці, так і ефективності використання в межах підприємства, держави.

Незважаючи на широке використання категорії «персонал» в науковому та економічному обігу, відсутня ії чітка ідентифікація та неузгодженість із нормативно-правовим полем України в сфері праці, що не дозволяє коректно використовувати це поняття в соціально-економічних дослідженнях.

Мета статті - ідентифікувати соціально-економічну категорію «персонал підприємства» із врахуванням термінології нормативно-правової бази України.

Викладення основного матеріалу. Вивчення наукового базису в сфері управління людиною, його еволюції свідчить про його багаторівневість, складність та неоднозначність сприйняття. Але, із впевненістю можна стверджувати, що роль людини завжди мала визначальне значення.

Слід зауважити високу різноманітність понять, які характеризують людину в процесі праці на кожному еволюційному етапі та на кожному ієрархічному рівні соціально-економічної системи.

Важливе значення має одиничний чи множинний підхід - одна людина/працівник чи колектив, населення тощо. Розмежування понять щодо людини в процесі праці та місце категорії «персонал» наведено на рисунку 1.

(C) В.В. Смачило, Т.Л. Наливайко, 2019 


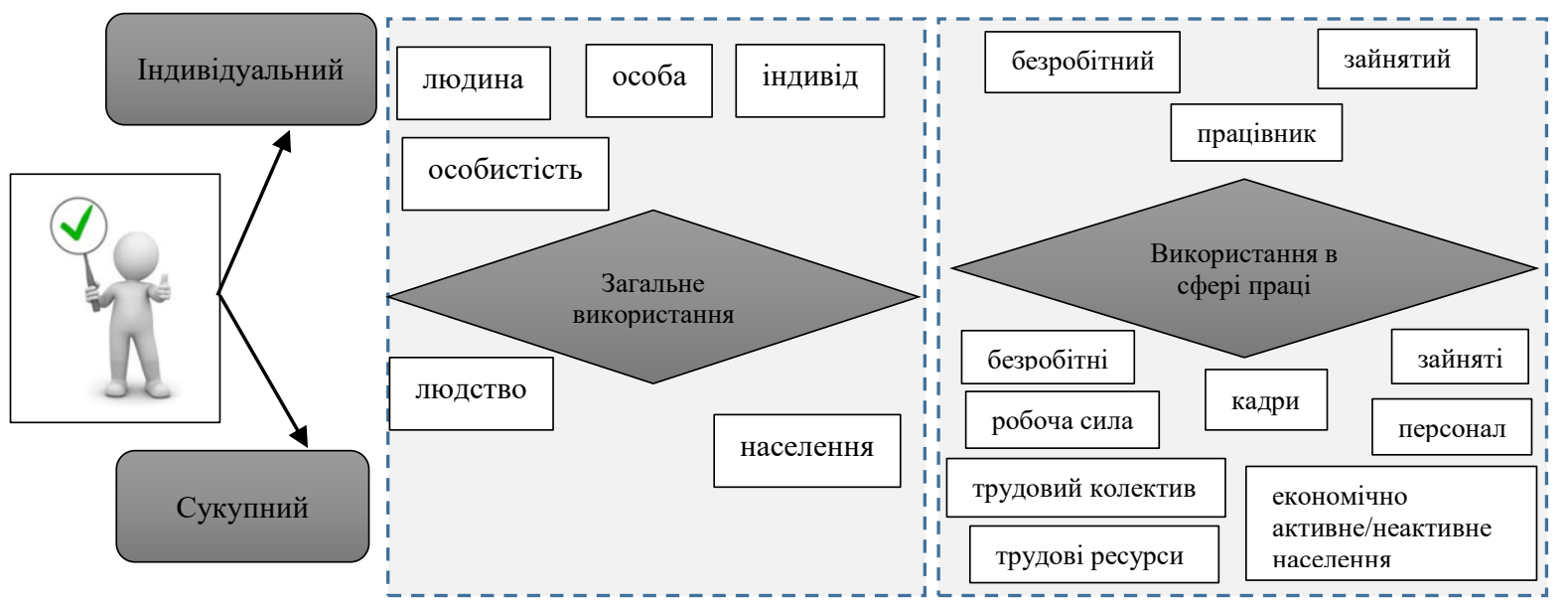

Рис. 1. Розмежування понять щзодо людини в процесі праці та місие категорї «персонал» (розроблено авторами)

Як бачимо з рисунка 1, кількість термінів, які характеризують сукупність людей у процесі праці, має найбільш диверсифікований характер. Саме тому в представленій множині необхідно визначити місце та сутнісне навантаження соціально-економічної категорії «персонал».

На індивідуальному рівні розглянемо терміни «зайнятий/безробітний» та «працівник» і їх розуміння в правовому полі України.

Визначення «безробітний» введено в обіг Законом України «Про зайнятість населення» та визначається як «особа віком від 15 до 70 років, яка через відсутність роботи не має заробітку або інших передбачених законодавством доходів як джерела існування, готова та здатна приступити до роботи» [1]. Категорію «безробітні» розкрито в [2] як «особи, які не мають роботи, активно ії шукають і готові приступити до неї впродовж наступних двох тижнів». До зайнятого населення, згідно 3 тим самим законодавчим актом, належать особи, які «працюють за наймом на умовах трудового договору (контракту) або на інших умовах, передбачених законодавством, особи, які забезпечують себе роботою самостійно (у тому числі члени особистих селянських господарств), проходять військову чи альтернативну (невійськову) службу, на законних підставах працюють за кордоном та які мають доходи від такої зайнятості, а також особи, що навчаються за денною формою у загальноосвітніх, професійно-технічних та вищих навчальних закладах та поєднують навчання з роботою» [1].

Більш широко представлено розуміння терміна «працівник» у правовому полі України (рис. 2). Провівши аналіз індивідуального рівня в сфері праці, виокремимо неузгодженість тлумачення терміна «працівник» та «найманий працівник». Узагальнимо, що, по-перше, працівник - це фізична особа; подруге, яка працює або виконує обов'язки або функції; по-третє, праця (виконання функцій/обов'язків) здійснюється на підставі не лише трудового договору, але й контракту (таке уточнення важливе, тому що 3 правового погляду вказані документи мають різну юридичну силу, тому будемо іх використовувати одночасно); по-четверте, працює у роботодавця, який може бути як підприємством, установою, організацією незалежно від форм власності, виду діяльності та господарювання (вказані інституції можуть бути представлені лише юридичними особами, тому, вважаємо, доречно уникнути перерахування, а використовувати широкий правовий термін - юридична особа), так і фізичною особою. Згідно 3 законодавчим визначенням [6], роботодавцем є власник підприємства, установи, організації незалежно від форми власності та виду діяльності або уповноважений ним орган чи фізична особа, яка відповідно до законодавства використовує найману працю. Термін «найманий працівник» зустрічався в [7], який вже втратив свою чинність та в [2], але за змістовним навантаженням вказані терміни збігаються 3 терміном «працівник».

Отже, працівник (працівники) - це фізична(i) особа(и), яка працює на підставі трудового договору (контракту) у роботодавця, яким може бути як юридична, так і фізична особа. Тобто ключовим $є$ наявність трудового договору або контракту, який має на увазі найм фізичної особи для праці, виконання певної роботи, функції, обов'язку та не має обмеження ні в термінах, ні в постійності. Визначившись 3 термінами індивідуального рівня, перейдемо до ідентифікації категорії «персонал» в термінологічній множині схожих понять. Проведемо його етимологічний та семантичний аналізи. 


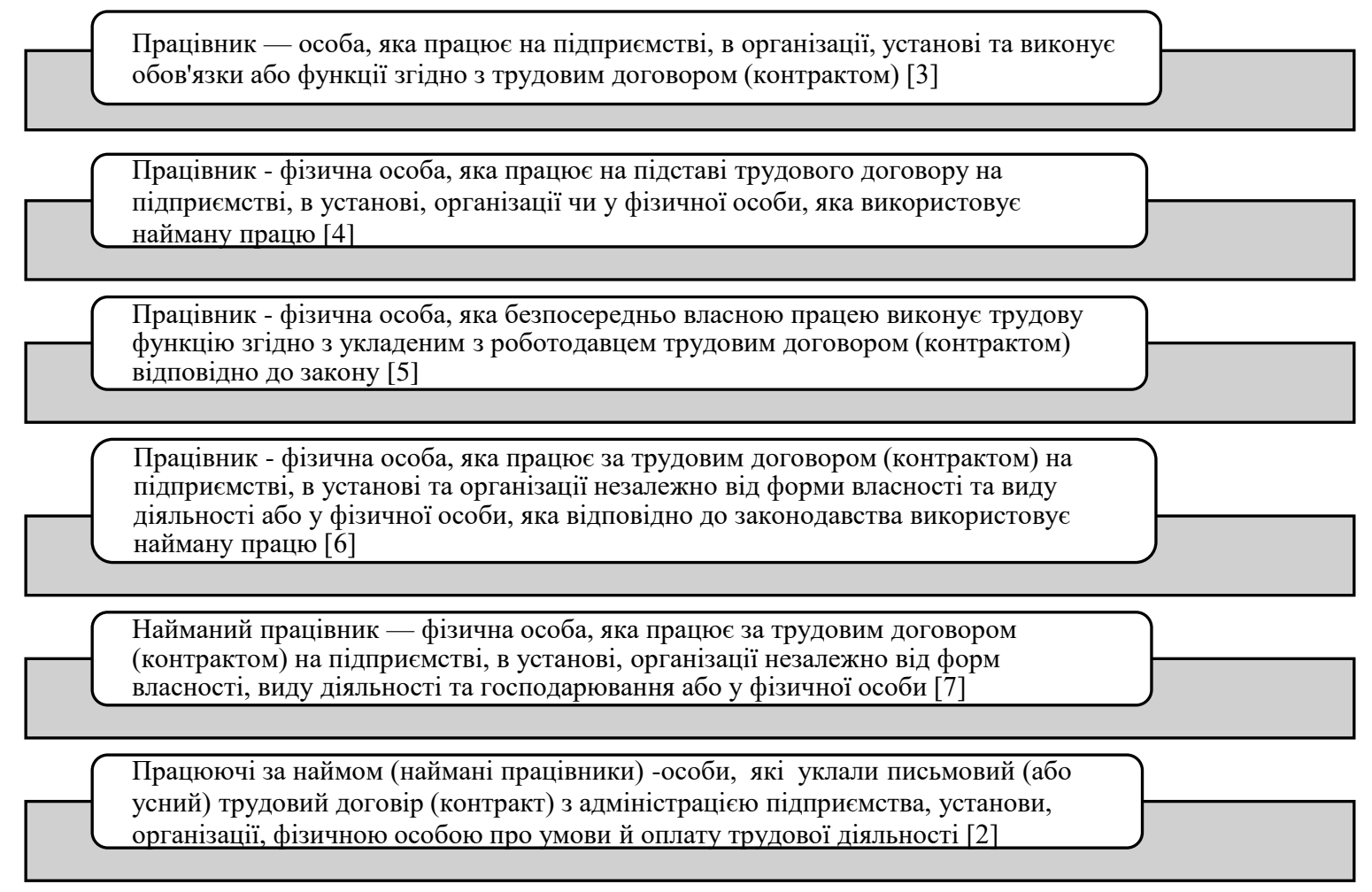

Рис. 2. Трактування терміна «працівник» у правовому полі Украӥни (узагальнено авторами на основі [2-7])

По-перше, етимологія цього поняття бере своє походження з латини: personalis - особистий, тобто базовим є особистість (лат. persona - особистість). Семантика цього поняття є досить неоднозначною та неусталеною. Зауважимо, що англійський варіант слова «персонал» виражається декількома словами «staff» та «personnel». Перше слово доцільно використовувати, коли ми говоримо про обслуговуючий персонал або службовців, а друге - коли характеризуємо працівників підприємства взагалі. Відповідно, є стійким словосполучення personnel management, хоча популярним і загальновживаним у західній літературі стосовно управління персоналом $є$ термін human resource management.

Вважається, що категорія «персонал» в український науковий обіг прийшов із досліджень західних економістів та враховує не лише штатних працівників підприємства, а й осіб поза штатом та власників [8].

По-друге, в правовому полі України відсутня ідентифікація такої складної соціально-економічної категорії як «персонал».

По-третє, слід зауважити, що у вітчизняній навчальній літературі персонал підприємства як ототожнюють з трудовими ресурсами [9], так і розмежовують [10]. Окрім того, відбувається ототожнення як $з$ кадрами [11], так і з трудовим колективом підприємства [10]. Саме тому необхідно визначити наведені на рисунку 2 поняття.

Так категорії зайняті та безробітні будемо розглядати згідно з їх тлумаченням в Законі України «Про зайнятість населення», що розглядалися вище. Терміни «економічно активне» та «економічно неактивне населення», введені в 1966 р. у міжнародний обіг, тісно пов'язане із поняттями зайнятого та безробітного населення, що розглядалося вище, та визначається згідно з [2]. «Економічно активне населення (робоча сила) - особи віком 15-70 років, які протягом певного періоду часу забезпечують пропозицію робочої сили на ринку праці. Економічно неактивне населення (населення поза робочою силою) - особи, які не мають роботи і не займаються ii пошуками, тобто не можуть бути класифіковані як «зайняті» або «безробітні». Як бачимо, вказані категорії - зайняті, безробітні, економічно активне/неактивне населення не використовується на рівні підприємства (установи, організації). Їх доцільно застосовувати на більш високих рівнях - держава, регіон, певна територія. В той самий час термін «робоча сила», який у ринковій економіці прирівнюється 3 економічно активним населенням, досить часто застосовується й до рівня підприємства, що на наш погляд не зовсім коректно.

Це пов'язано із ще одним терміном, характерним для планово-адміністративної економіки, - «трудові ресурси». Його булло введено до наукового економічного обігу ще у 20-х роках минулого сторіччя С.Струміліним для вимірювання саме робочої сили [5]. Категорії «трудові ресурси» та «економічно активне населення» кількісно не є ідентичними. Так О.А. Грішнова вважає поняття «трудові ресурси» 
ширше, аніж поняття «економічно активне населення» [13] та кількісно визначається населенням, яке фізично здатне працювати, а остання категорія кількісно визначається реальною частиною трудових ресурсів, що добровільно працює або хоче працювати [8].

Кадри, на думку [12], відрізняються від персоналу тим, що представляють собою лише частину персоналу, який має високу кваліфікацію

Щоб уникнути деформації наукового сприйняття цієї категорії, проведемо морфологічний аналіз існуючих визначень «персонал». Існуючі узагальнення категорії «персонал» автором представлено в таблиці 1.

Таблиия 1

Узагальнення визначень «персонал», щзо існують в сучасному науковому просторі

(побудовано авторами)

\begin{tabular}{|c|c|}
\hline Сутнісне навантаження & Джерело \\
\hline $\begin{array}{l}\text { Персонал - працівники підприємства, установи, організації, які виконують роботи, пов’язані } 3 \\
\text { експлуатацією ядерних установок, об'єктів, призначених для поводження } 3 \text { радіоактивними } \\
\text { відходами, інших джерел іонізуючого випромінювання }\end{array}$ & [14] \\
\hline $\begin{array}{l}\text { Персонал підприємства (кадри, трудовий колектив) - це сукупність працівників, що входять до } \\
\text { його облікового складу }\end{array}$ & {$[10]$} \\
\hline $\begin{array}{l}\text { Трудові ресурси (персонал) підприємства - це сукупність постійних працівників, які одержали } \\
\text { необхідну професійну підготовку та/або мають практичний досвід і навички роботи, вкладають } \\
\text { іх у проведення господарсько-фінансової діяльності підприємства }\end{array}$ & [9] \\
\hline $\begin{array}{l}\text { Персонал (кадри) підприємства - це сукупність постійних працівників, які отримали необхідну } \\
\text { професійну підготовку і забезпечують господарську діяльність }\end{array}$ & [11] \\
\hline $\begin{array}{l}\text { Персонал - основний, постійний штатний склад кваліфікованих працівників, який формується і } \\
\text { змінюється під впливом як внутрішніх, так і зовнішніх факторів }\end{array}$ & {$[12]$} \\
\hline $\begin{array}{l}\text { Персонал підприємства - особистий склад підприємства, що враховує всіх найманих } \\
\text { працівників, а також працюючих власників і співвласників }\end{array}$ & {$[15]$} \\
\hline $\begin{array}{l}\text { Персонал підприємства - це працівники, які отримали необхідну професійну підготовку та } \\
\text { мають досвід практичної діяльності }\end{array}$ & [17] \\
\hline $\begin{array}{l}\text { Персонал підприємства - сукупність системопов'язаних працівників } 3 \text { їх особистісними } \\
\text { характеристиками, знаннями, вміннями, навиками роботи у колективі, які вони використовують } \\
\text { у трудовій діяльності }\end{array}$ & {$[16]$} \\
\hline $\begin{array}{l}\text { Персонал - це основний штатний склад працівників підприємства (організації), що володіють } \\
\text { необхідною кваліфікацією і виконують різноманітні виробничо-господарські функції }\end{array}$ & {$[18]$} \\
\hline $\begin{array}{l}\text { Персонал - це весь особовий склад організації, всі постійні та тимчасові працівники, } \\
\text { представники кваліфікованої і некваліфікованої праці }\end{array}$ & [19] \\
\hline $\begin{array}{l}\text { Під персоналом підприємства розуміється сукупність найнятих працівників різних професійно- } \\
\text { кваліфікаційних груп, зайнятих на підприємстві відповідно до штатного розкладу, а також } \\
\text { працюючі власники організації, які одержують на підприємстві (фірмі) заробітну плату. Поняття } \\
\text { «персонал» більш містке, воно враховує весь особовий склад тих, хто працює на підприємстві, а } \\
\text { саме: працівників облікового складу; осіб, прийнятих на роботу за сумісництвом з інших } \\
\text { підприємств; осіб, які виконують роботи за договорами цивільно-правового характеру }\end{array}$ & {$[20]$} \\
\hline $\begin{array}{l}\text { Персонал підприємства - це сукупність постійних працівників, які отримали необхідну } \\
\text { професійну підготовку та (або) мають досвід практичної діяльності }\end{array}$ & {$[21]$} \\
\hline $\begin{array}{l}\text { Персонал підприємства - це сукупність постійних працівників, які отримали необхідну } \\
\text { професійну підготовку і забезпечують господарську діяльність }\end{array}$ & {$[22,24]$} \\
\hline $\begin{array}{l}\text { Персонал підприємства - штатні кваліфіковані працівники з певною професійною підготовкою, } \\
\text { які мають спеціальні знання, трудові навички чи досвід роботи в обраній проблеми теорії та } \\
\text { методології бухгалтерського обліку, контролю і аналізу }\end{array}$ & {$[23,24]$} \\
\hline $\begin{array}{l}\text { Персонал підприємства являє собою сукупність працівників різних професійно-кваліфікаційних } \\
\text { рівнів, зайнятих на підприємстві, які входять до його облікового складу. В облікову кількість } \\
\text { штатних працівників враховуються усі наймані працівники, які уклали письмово трудовий } \\
\text { договір (контракт) і виконували постійну, тимчасову або сезонну роботу один день і більше }\end{array}$ & {$[25,26]$} \\
\hline $\begin{array}{l}\text { Персонал підприємства - особовий склад кваліфікованих робітників підприємства, фірми або } \\
\text { організації, які володіють професійною здатністю до праці, тобто мають спеціальну підготовку } \\
\text { та потребують грамотного управління і створення умов для їхнього розвитку, а також здатні до } \\
\text { змін відповідно до розвитку інших факторів і елементів виробництва. }\end{array}$ & {$[27]$} \\
\hline $\begin{array}{l}\text { Персонал підприємства - особовий склад організації, який враховує працівників, що працюють } \\
\text { за наймом, а також власників та співвласників, що працюють на підприємстві. }\end{array}$ & {$[8,28]$} \\
\hline $\begin{array}{l}\text { Персонал підприємства - склад робітників (працівників - aвm.), що представляють кваліфіко } \\
\text { і некваліфіковану працю }\end{array}$ & {$[8,29]$} \\
\hline
\end{tabular}


Із визначень, що наведені в таблиці 1, можемо виокремити неусталеність думок науковців 3 цього приводу. Вважаємо, що слід розмежовувати нормативно-правове поле, де відсутнє закріплене загальне поняття «персонал», а також науково-економічне поле, де поняття «персонал» $€$ широковживаним.

У наведених визначеннях підводиться нормативно-правова база, шляхом застосування таких понять, як «працівник», «трудовий колектив», «облікова кількість штатних працівників», «обліковий склад», основний, постійний, штатний склад (працівники), «особовий склад».

Отже, маємо декілька підходів до розуміння поняття «персонал», сформованих на основі морфологічного аналізу (рис. 3).

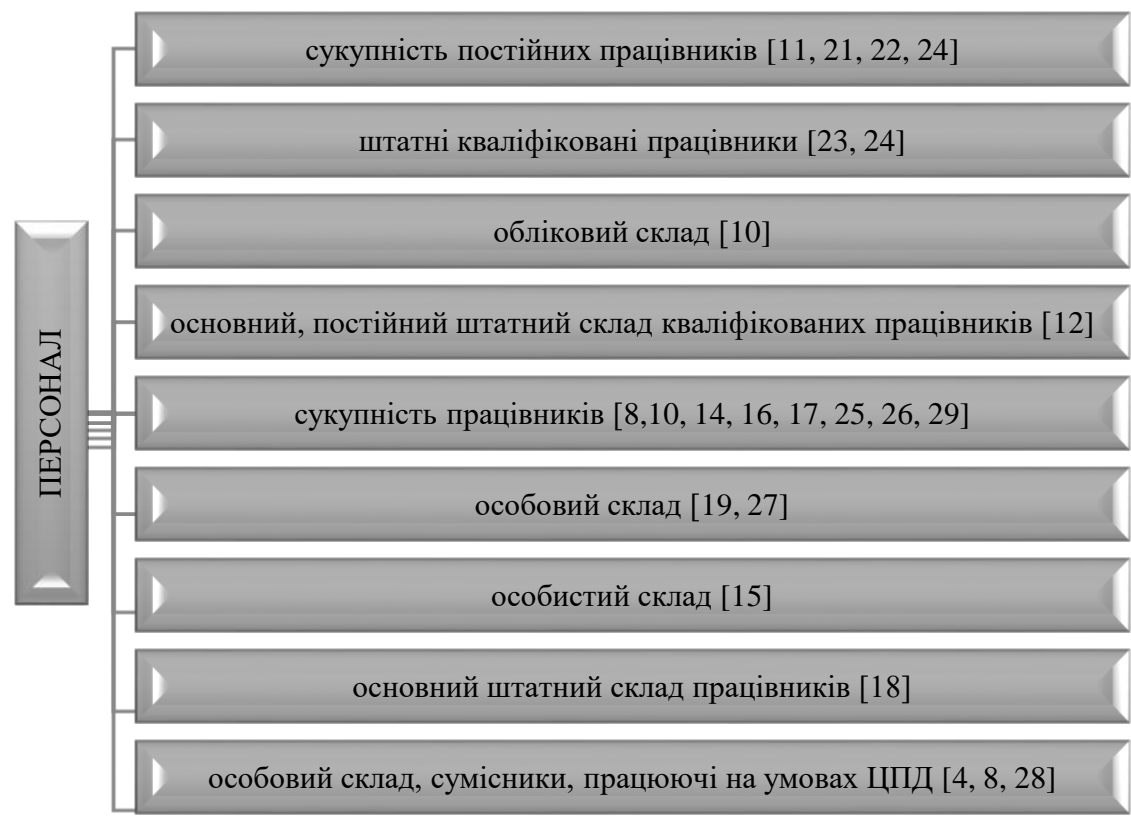

Рис. 3. Морфологічний аналіз категорії «персонал» (побудовано авторами)

Термін «особовий склад»є в законодавчому полі України [30], але доречний лише для військової сфери, Національної Гвардії, Спецзв'язку, Державної кримінально-виконавчої служби, тому вживати його як синонім персоналу для будь-яких суб'єктів господарювання недоречно.

Термін «постійний склад» також характерний для військової сфери. Тому під час ідентифікації категорії персонал доцільно уникати терміна «склад», адже його застосування властиве для військової сфери.

Крім того, термін «обліковий склад» використовується в планово-адміністративній економіці в Інструкції зі статистики чисельності працівників, зайнятих у народному господарстві (1995 р.), яка втратила чинність у 2005 p.

У обліковий склад працівників підприємства мають враховуватися всі працівники, які прийняті на постійну, сезонну, а також на тимчасову роботу строком один день і більше з дня зарахування їх на роботу. У обліковому складі працівників за кожний календарний день враховуються як фактично працюючі, так $\mathrm{i}$ відсутні на роботі з будь-яких причин, тобто усі працівники, які перебувають у трудових відносинах, незалежно від форми договору. В Інструкції 2005 р. [31] таке поняття, як «обліковий склад» чітко не прописане, але використовується, в той самий час застосовується термін - «облікова кількість штатних працівників». Із визначень [25, 26], вказані терміни урівнюються між собою.

Такі характеристики працівників/складу як основний, постійний, штатний не знаходять свого відображення в нормативно-правовому полі в повному обсязі та конкретно, тому рекомендовано не використовувати їх для опису категорії «персонал», адже неконкретні характеристики будуть розмивати ії сутнісне навантаження. В той самий час простежуємо наявність понять, які можуть стати базовим для вказаних характеристик.

Так термін «основне місце роботи» визначене в [32], це - місце роботи, де працівник працює на підставі укладеного трудового договору, де знаходиться (оформлена) його трудова книжка, до якої вноситься відповідний запис про роботу.

Визначення категорії постійних працівників не представлено в сучасному правовому полі України, але існують роз'яснення щодо тимчасових та сезонних працівників. Так «тимчасовими вважаються працівники, яких прийнято на роботу на строк до двох місяців, а для заміщення тимчасово відсутніх працівників, за якими зберігається їх місце роботи (посада), - до чотирьох місяців [33, 34]. У свою чергу сезонними працівниками вважаються «ті, які виконують роботу, включену до Списку № 278, і тривалість якої не перевищує шести місяців. Причому ці дві умови мають бути виконані одночасно» $[33,35,36]$. 
Визначення категорії «постійні працівники» наведено в [37] і до них належать ті особи, які $є$ «членами підприємства або прийняті на роботу по найму на тривалий термін без його точного визначення». Тобто, працюють за трудовим договором/контрактом на визначений тривалий термін (понад 6 місяців). В той самий час не зовсім зрозуміло, які особи є членами підприємства, що робить це визначення частково розмитим. Вважаємо, що штатний склад чи штатних працівників слід розглядати через призму штатного розпису. Його розуміють як «затверджуваний власником, керівником чи вищим органом підприємства, установи, організації внутрішній нормативний документ, який містить перелік назв і кодів структурних підрозділів організації, назв і кодів посад працівників відповідно до Класифікатора професій, із зазначенням кількості штатних одиниць за кожною посадою (з урахуванням вакансій), розмірів посадових окладів, доплат і надбавок, та фонду заробітної плати» [38].

У роз'ясненнях для працівників кадрових служб [39] вказано, що «штатна чисельність працівників це встановлений на перше число звітного періоду роботодавцем склад працівників, з якими укладено трудовий договір відповідно до затвердженого роботодавцем переліку посад (з урахуванням вакантних), де зазначено розмір окладу для конкретної посади». Тобто штатна чисельність формується відповідно до штатного розпису на основі укладання трудових договорів не залежно від тривалості договору та статусу працюючого (сумісник чи ні). Виходячи з визначення штатного розпису, штатні працівники - це ті фізичні особи, які працюють за трудовим договором/контрактом на підприємстві у межах та кількості посад, що визначені в штатному розписі. В той самий час слід зауважити, що вказані особи можуть знаходитися у тимчасових трудових взаємовідносинах або строкових. Отже, не лише постійні, але й сумісники будуть входити до категорії штатні працівники. Окрім того, на штатних посадах можуть працювати особи, які працюють на умовах зовнішнього сумісництва.

В Інструкції зі статистики кількості працівників [31] наведене визначення облікової кількості штатних працівників, до якої враховуються «усі наймані працівники, які уклали письмово трудовий договір (контракт) і виконували постійну, тимчасову або сезонну роботу один день і більше, а також власники підприємства, якщо, крім доходу, вони отримували заробітну плату на цьому підприємстві».

В цьому визначенні чітко не визначено, на яких умовах і за що власник підприємства отримує заробітну плату (вважаємо, що правовою основою для цього має бути трудовий договір/контракт, тобто власник може обіймати певну посаду згідно з штатним розписом).

Поняття трудового колективу наведено в ст. 252 КЗПП та в ст. 65 Господарського кодексу України [40, 41], де «трудовий колектив підприємства утворюють усі громадяни, які своєю працею беруть участь у його діяльності на основі трудового договору (контракту, угоди), а також інших форм, що регулюють трудові відносини працівника з підприємством».

Тобто трудовий колектив є найбільш широкою категорією, яка охоплюватиме не лише осіб, які працюють на умовах трудового договору/контракту на тривалий період, на посадах, що входять до штатного розпису. Розуміння трудового колективу, на наш погляд, відповідає показнику загальної кількості працівників [31], який, крім штатних працівників, враховує кількість зовнішніх сумісників і працюючих за цивільно-правовими договорами.

Під сумісництвом розуміють «виконання працівником, крім своєї основної, іншої регулярної оплачуваної роботи на умовах трудового договору у вільний від основної роботи час в тій самій чи іншій організації або у громадянина (підприємця, приватної особи) за наймом» $[42,43]$. Розрізняють внутрішнє та зовнішнє сумісництво. Перше передбачає, що працівник у вільний від основної роботи час виконує іншу роботу, на умовах трудового договору, в тій самій організації, а зовнішнє - те саме, але в іншій організації [42]. Базуючись на зазначеному, можемо стверджувати, що, сукупність працівників відповідає обліковій кількості штатних працівників (остання прирівнюється до облікового складу), а трудовий колектив загальній чисельності підприємства.

Виходячи з проведеного аналізу, кількісне обмеження персоналу та його відмінність від інших категорій, буде базуватися на обліковій кількості штатних працівників. Це обгрунтовується тим, що: розкривши поняття, які закладено у визначеннях таблиці 1, можемо зауважити, що більшість авторів тлумачать персонал у межах облікової кількості штатних працівників.

Досить часто до характеристик персоналу зараховують кваліфікаційний рівень - він має бути високим, що більше характерно для категорії «кадри», яку розглянуто вище. Отже, вказане обмеження вважаємо некоректним для ідентифікації поняття «персонал». Критерій постійності, тобто взаємовідносини 3 працівниками, які виконують постійну роботу на умовах тривалого трудового договору/контракту, виключає категорію працівників, які виконують тимчасові та сезонні види робіт. У цьому випадку виникає питання щодо можливості ними управляти. Адже вони також підпадають під управління, адже входять до штату роботодавця.

Критерій штатності поширюється не лише на облікових штатних працівників, але й на зовнішніх сумісників, адже з ними також укладаються трудові договори (контракти) на виконання певної роботи за посадою, що $є$ в штатному розписі. Вважаємо цю категорію працівників також треба враховувати в кількісному вираженні категорії персонал, адже зовнішні сумісники підпадають під управління з боку роботодавця. 
Отже, особи, які належать до облікової кількості штатних працівників, та зовнішні сумісники вступають у трудові взаємовідносини із роботодавцем на основі трудового договору/контракту, в основі якого організація процесу праці, а предметом є сам процес праці, без передбачення кінцевого результату на посаді, що передбачені штатним розписом. Взаємовідносини між роботодавцем і працівником у цьому випадку регулюються Кодексом законів про працю України [40].

Взаємовідносини за цивільно-правовими договорами, сторонами яких $\epsilon$ замовник та підрядник/виконавець, регулюються Цивільним Кодексом України [44], а метою є результат роботи, а не організація їі процесу як у випадку з трудовим договором (контрактом).

Відповідно, категорія осіб, які взаємодіють на основі цивільно-правового договору, фактично не $\epsilon$ працівниками роботодавця. Відповідно, це дає право не враховувати їх в чисельність працівників роботодавця. Що викликає певну колізію із Інструкцією зі статистики чисельності працівників.

Отже, маємо розмежування стосовно категорії «персонал», яке візуалізовано на рисунку 4.

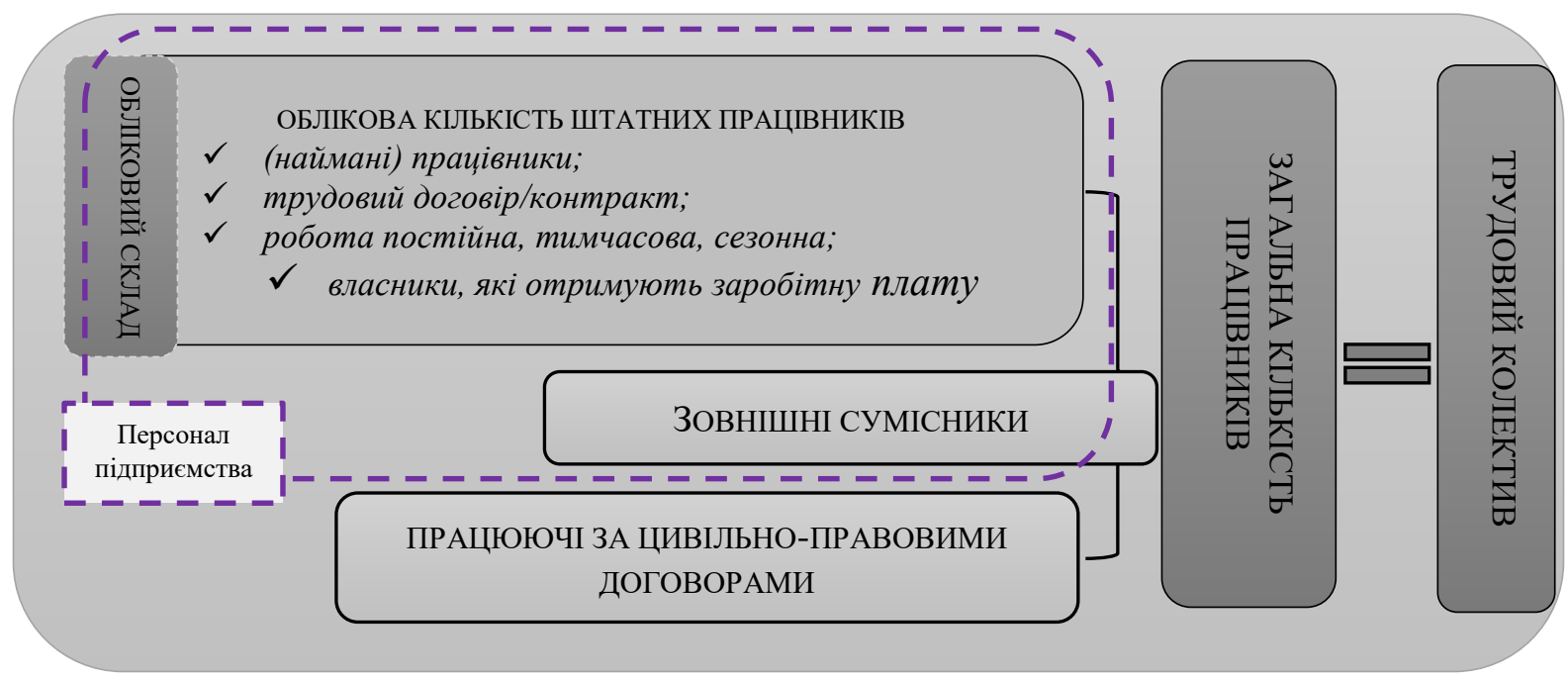

Рис. 4. Взаємовідношення понять в ідентифікаиії категорії «персонал» (побудовано авторами)

Проведене дослідження дозволяє представити авторське бачення персоналу: це фізичні особи, що мають трудові взаємовідносини із роботодавцем на основі трудового договору/контракту, тобто це всі працівники роботодавця з точки зору тлумачення працівника як такого.

Із врахуванням особливостей господарської діяльності підприємств в Україні (фізичні особироботодавці не ведуть звітність щодо облікової кількості штатних працівників, а підприємства $\epsilon$ юридичними особами), персонал підприємства - це сукупність фізичних осіб, які мають трудові взаємовідносини із роботодавцем на основі трудового договору/контракту та кількісно представляють собою суму облікової кількості штатних працівників підприємства та зовнішніх сумісників.

3 точки зору управління та розвитку персоналу, який передбачає інвестиції, доцільність вкладення в осіб, які мають нестійкі трудові взаємовідносини з роботодавцем, має сумнівний характер, але управління категорією зовнішніх сумісників має безпосереднє місце на підприємстві. Тому, не дивлячись на таку колізію, вказаних працівників слід враховувати в чисельність персоналу, але виважено ставитися до них у процесі управління.

Висновки та перспективи подальших досліджень.

Отже, проаналізовано термінологію стосовно людини в сфері праці та узгоджено із нормативноправовим забезпеченням України. Представлено авторське розуміння соціально-економічної категорії «персонал підприємства» як об'єкта управління: персонал підприємства - це сукупність фізичних осіб, які мають трудові взаємовідносини із роботодавцем на основі трудового договору/контракту та кількісно являють собою суму облікової кількості штатних працівників підприємства та зовнішніх сумісників.

До перспектив подальших досліджень слід зарахувати формування визначення категорії «адаптивне управління персоналом підприємства», яке буде відповідати сучасним науково-економічним запитам.

\section{Список використаної літератури:}

1. Про зайнятість населення : закон України / Верховна Рада України [Електронний ресурс]. - Режим доступу : https://zakon.help/law/5067-VI/edition20.01.2018/.

2. Методологічні положення класифікації та аналізу стану економічно активного населення : наказ від 19 січня 2011 p. № 12. / Державний комітет статистики України : ред. від. 14.01.2016 [Електронний ресурс]. - Режим доступу : http://www.ukrstat.gov.ua/metod_polog/metod_doc/2011/12/metod.htm.

3. Про охорону праці : закон України / Верховна Рада України [Електронний ресурс]. - Режим доступу : https://zakon.rada.gov.ua/laws/show/2694-12. 
4. Про професійні спілки, їх права та гарантії діяльності : закон України / Верховна Рада України [Електронний pecypc]. - Режим доступу : https://zakon.rada.gov.ua/laws/show/1045-14.

5. Податковий кодекс України / Верховна Рада України [Електронний ресурс]. - Режим доступу : https://zakon.rada.gov.ua/laws/show/2755-17.

6. Про професійний розвиток працівників : закон України / Верховна Рада України [Електронний ресурс]. Режим доступу : https://zakon.rada.gov.ua/laws/show/4312-17.

7. Про загальнообов'язкове державне соціальне страхування у зв'язку з тимчасовою втратою працездатності та витратами, зумовленими похованням : закон України / Верховна Рада України [Електронний ресурс]. Режим доступу : https://zakon.rada.gov.ua/laws/show/2240-14 (втратив чинність*).

8. Смачило В.В. Дефініція категорій, які визначають роль людини в соціально-економічних процесах / B.B. Смачило, M.B. Корпан // Траектория науки : электронный научный журнал. - 2016. - № 1 (6) [Електронний ресурс]. - Режим доступу : http://pathofscience.org/index.php/ps/article/view/34.

9. Нестеренко В.Ю. Економіка виробництва : конспект лекцій / В.Ю. Нестеренко, I.I. Токар. - Харків, 2012 [Електронний ресурс]. - Режим доступу : https://buklib.net/books/37312/.

10. Гетьман О.О. Економіка підприємства / О.О. Гетьман, В.М. Шаповал [Електронний ресурс]. - Режим доступу : https://pidruchniki.com/15060913/ekonomika/personal_pidpriyemstva.

11. Економіка підприємства / Електронна бібліотека економіста : реферати, курсові, підручники / Буковинська бібліотека [Електронний ресурс]. - Режим доступу : https://buklib.net/books/24836/.

12. Управління персоналом / Електронна бібліотека економіста : реферати, курсові, підручники / Івано-Франківська обласна універсальна наукова бібліотека ім. І.Франка [Електронний ресурс]. - Режим доступу : https://library.if.ua/book/45/3054.html.

13. Грішнова О.А. Економіка праці та соціально-трудові відносини : підручник / О.А. Грішнова. - Київ : Знання, 2006. $-559 \mathrm{c}$.

14. Про використання ядерної енергії та радіаційну безпеку : закон України / Верховна Рада України [Електронний pecypc]. - Режим доступу : https://zakon.rada.gov.ua/laws/show/39/95-\%D0\%B2\%D1\%80.

15. Економіка підприємства : короткий курс лекцій з дисципліни [Електронний ресурс]. - Режим доступу : https://studme.com.ua/1584072013202/ekonomika/ekonomika_predpriyatiya.htm.

16. Якубів Р.Д. Класифікація персоналу підприємства: управлінський підхід / Р.Д. Якубів // Інноваційна економіка. - 2014. - № 3. - С. 131-136.

17. Економічне промислове підприємництво / Електронна бібліотека для студента [Електронний ресурс]. - Режим доступу : http://ebooktime.net/book_176_glava_33_6\%C2\%A0_\%C2\%A0\%D0\%9F\%D0\%95\%D0\%A0\%D0\%A1\%D0\%9E\%D0\%9D $\%$ D0\%90\%D0\%9B.html.

18. Шолубко Д.І. Сутність підбору персоналу в організації / Д.І. Шолубко [Електронний ресурс]. - Режим доступу : http://ena.lp.edu.ua/bitstream/ntb/13319/1/285_Sholubko_738-739_69.pdf.

19. Никифоренко В.Г. Управління персоналом : навч. посібник / В.Г. Никифоренко. - 2-ге вид., випр. та доп. Одеса : Атлант, 2013. - 275 с.

20. Гринчуцький B.I. Економіка підприємства / В.I. Гринчуцький [Електронний ресурс]. - Режим доступу : https://westudents.com.ua/glavy/15050-tema-7-personal-pdprimstva-produktivnst-oplata-prats.html.

21. Персонал підприємства : електронна книга / Редакційно-видавничий центр / Чорноморський державний університет імені Петра Могили [Електронний ресурс]. - Режим доступу : http://lib.chmnu.edu.ua/pdf/metodser/90/8.pdf.

22. Качан Є.П. Управління трудовими ресурсами : навч. посібник / С.П. Качан, Д.Г. Шушпанов. - К. : Юридична книга, 2009. - $358 \mathrm{c}$.

23. Швиданенко Г.О. Економіка підприємства : навч.-метод. посібник / Г.О. Швиданенко, О.С. Федонін. - К. : KHEУ, 2009. - $439 \mathrm{c}$.

24. Ткачук Г.Ю. Еволюція засад управління людським капіталом / Г.Ю. Ткачук, В.В. Савіuький // Проблеми теорії та методології бухгалтерського обліку, контролю і аналізу. Серія : Бухгалтерський облік, контроль і аналіз. 2014. - Вип. 3. - С. 369-377 [Електронний ресурс]. - Режим доступу : http://nbuv.gov.ua/UJRN/ptmbo_2014_3_27.

25. Басюркіна Н.Й. Проблеми ефективного використання персоналу на підприємствах України / Н.Й. Басюркіна, Л.Н. Мартолога // Market economy: modern management theory and practice. - Vol. 15, Issue 2 (33). - Pp. 63-72 [Електронний ресурс]. - Режим доступу : http://rinek.onu.edu.ua/article/view/120438/

26. Кіндрацька Г.І. Економічний аналіз : теорія і практика : підручник / Г.І. Кіндрачька, М.С. Білик, А.Г. Загородній. - Львів : Магнолія 2006, 2008. - 440 с.

27. Русінко M.I. Еволюція поняття "персонал підприємства" та теоретичні підходи до його визначення / M.I. Русінко, О.І. Судакова, Г.О. Ларченко // Ефективна економіка. - 2015. - № 3 [Електронний ресурс]. - Режим доступу : http://nbuv.gov.ua/UJRN/Nvmgu_eim_2017_27(1)_24.

28. Управление персоналом организации : практикум / под ред. А.Я. Кибанова. - Москва : ИНФРА-М, 2001. -296 с.

29. Шегда А.В. Менеджмент : навч. посібник / А.В. Шегда. - Київ : Знання ; КОО, 2002. - 583 с.

30. Особовий склад : термін [Електронний ресурс]. - Режим доступу : https://zakon.rada.gov.ua/laws/term/35169.

31. Інструкція зі статистики кількості працівників [Електронний ресурс]. - Режим доступу : https://zakon.rada.gov.ua/laws/show/z1442-05.

32. Про збір та облік єдиного внеску на загальнообов'язкове державне соціальне страхування : закон України / Верховна Рада України [Електронний ресурс]. - Режим доступу : https://zakon.rada.gov.ua/laws/show/2464-17.

33. Тимчасові та сезонні працівники: прийняття на роботу й оплата праці [Електронний ресурс]. - Режим доступу : https://prohr.rabota.ua/timchasovi-ta-sezonni-pratsivniki-priynyattya-na-robotu-y-oplata-pratsi/. 
34. Про умови праці тимчасових робітників і службовців : указ СРСР : від 24 вересня 1974 р. № 311-09 / Президія Верховної Ради СРСР.

35. Про умови праці робітників і службовців, зайнятих на сезонних роботах : указ СРСР від 24 вересня $1974 \mathrm{p}$. № 310-09 / Президія Верховної Ради СРСР.

36. Список сезонних робіт і сезонних галузей : постанова : від 28 березня 1997 р. № 278 / Кабінет Міністрів України.

37. Андрійчук В.Г. Економіка аграрних підприємства : підручник / В.Г. Андрійчук. - 2-ге вид., доп. і перероб. - К. : КНЕУ, 2002. - 624 с. [Електронний ресурс]. - Режим доступу : https://buklib.net/books/26406/.

38. Штатний розпис підприємства: порядок складання та форма / Міністерство праці України [Електронний pecypc]. - Режим доступу : https://www.kadrovik01.com.ua/article/3571-qqq-17-m2-poryadok-skladannyashtatnogo-rozpisu.

39. Звіт з єдиного внеску: як визначити штатну чисельність працівників / Міністерство праці України [Електронний ресурс]. - Режим доступу : https://www.kadrovik.ua/novyny/zvit-z-iedinogo-vnesku-yakviznachiti-shtatnu-chiselnist-pracivnikiv.

40. Кодекс законів про працю України / Верховна Рада України [Електронний ресурс]. - Режим доступу : https://zakon.rada.gov.ua/laws/show/322-08.

41. Господарський кодекс України / Верховна Рада України [Електронний ресурс]. - Режим доступу : https://zakon.rada.gov.ua/laws/show/436-15.

42. Робота за сумісництвом: від прийняття до звільнення / Міністерство праці України [Електронний ресурс]. Режим доступу : https://www.kadrovik01.com.ua/article/105-qqq-16-m5-19-05-2016-robota-za-sumsnitstvom-vdpriynyattya-do-zvlnennya.

43. Положення про умови роботи за сумісництвом працівників державних підприємств, установ і організацій : наказ від 28.06.1993 № 43 / Мінпраці України ; Мін’юст України ; Мінфін України.

44. Цивільний Кодекс України / Верховна Рада України [Електронний ресурс]. - Режим доступу : https://zakon.rada.gov.ua/laws/show/435-15.

\section{References:}

1. Verhovna Rada Ukrai'ny (2018), «Pro zajnjatist' naselennja», zakon Ukrai'ny, [Online], available at: https://zakon.help/law/5067-VI/edition20.01.2018/

2. Derzhavnyj komitet statystyky Ukrai'ny (2011), «Metodologichni polozhennja klasyfikacii' ta analizu stanu ekonomichno aktyvnogo naselennja», nakaz, vid 19 sichnja, N 12, red. vid 14 sichnja 2016, [Online], available at: http://www.ukrstat.gov.ua/metod_polog/metod_doc/2011/12/metod.htm

3. Verhovna Rada Ukrai'ny, «Pro ohoronu praci», zakon Ukrai'ny, [Online], available at: https://zakon.rada.gov.ua/laws/show/2694-12

4. Verhovna Rada Ukrai'ny, «Pro profesijni spilky, i'h prava ta garantii' dijal'nosti», zakon Ukrai'ny, [Online], available at: https://zakon.rada.gov.ua/laws/show/1045-14

5. Verhovna Rada Ukrai'ny, «Podatkovyj kodeks Ukrai'ny», [Online], available at: https://zakon.rada.gov.ua/laws/show/2755-17

6. Verhovna Rada Ukrai'ny, «Pro profesijnyj rozvytok pracivnykiv», zakon Ukrai'ny, [Online], available at: https://zakon.rada.gov.ua/laws/show/4312-17

7. Verhovna Rada Ukrai'ny, «Pro zagal'noobov'jazkove derzhavne social'ne strahuvannja u zv'jazku z tymchasovoju vtratoju pracezdatnosti ta vytratamy, zumovlenymy pohovannjam», zakon Ukrai'ny, vtratyv chynnist', [Online], available at: https://zakon.rada.gov.ua/laws/show/2240-14.

8. Smachylo, V.V. and Korpan, M.V. (2016), «Definicija kategorij, jaki vyznachajut' rol' ljudyny v social'noekonomichnyh procesah», Traektoryja nauky, эlektronnыj nauchnыj zhurnal, No. 1 (6), [Online], available at: http://pathofscience.org/index.php/ps/article/view/34

9. Nesterenko, V.Ju. and Tokar, I.I. (2012), Ekonomika vyrobnyctva, konspekt lekcij, Harkiv, [Online], available at: https://buklib.net/books/37312/

10. Get'man, O.O. and Shapoval, V.M., Ekonomika pidpryjemstva, [Online], available at: https://pidruchniki.com/15060913/ekonomika/personal_pidpriyemstva

11. Bukovyns'ka biblioteka, «Ekonomika pidpryjemstva», Elektronna biblioteka ekonomista: referaty, kursovi, pidruchnyky, [Online], available at: https://buklib.net/books/24836/

12. Ivano-Frankivs'ka oblasna universal'na naukova biblioteka im. I.Franka, «Upravlinnja personalom», Elektronna biblioteka ekonomista: referaty, kursovi, pidruchnyky, [Online], available at: https://library.if.ua/book/45/3054.html

13. Grishnova, O.A. (2006), Ekonomika praci ta social'no-trudovi vidnosyny, Znannja, Kyi'v, 559 p.

14. Verhovna Rada Ukrai'ny, «Pro vykorystannja jadernoi' energii' ta radiacijnu bezpeku», zakon Ukrai'ny, [Online], available at: https://zakon.rada.gov.ua/laws/show/39/95-\%D0\%B2\%D1\%80

15. «Ekonomika pidpryjemstva», korotkyj kurs lekcij z dyscypliny, [Online], available at: https://studme.com.ua/1584072013202/ekonomika/ekonomika_predpriyatiya.htm

16. Jakubiv, R.D. (2014), «Klasyfikacija personalu pidpryjemstva: upravlins'kyj pidhid», Innovacijna ekonomika, No. 3, pp. 131-136.

17. Elektronna biblioteka dlja studenta, «Ekonomichne promyslove pidpryjemnyctvo», [Online], available at: http://ebooktime.net/book_176_glava_33_6\%C2\%A0_\%C2\%A0\%D0\%9F\%D0\%95\%D0\%A0\%D0\%A1\%D0\%9E $\% \mathrm{D} 0 \% 9 \mathrm{D} \% \mathrm{D} 0 \% 90 \% \mathrm{D} 0 \% 9 \mathrm{~B} . \mathrm{html}$

18. Sholubko, D.I., Sutnist' pidboru personalu $v$ organizacii', [Online], available at: http://ena.lp.edu.ua/bitstream/ntb/13319/1/285_Sholubko_738-739_69.pdf 
19. Nykyforenko, V.G. (2013), Upravlinnja personalom, $2^{\text {nd }}$ ed., vypr. ta dop., Atlant, Odesa, 275 p.

20. Grynchuc'kyj, V.I., Ekonomika pidpryjemstva, [Online], available at: https://westudents.com.ua/glavy/15050-tema7-personal-pdprimstva-produktivnst-oplata-prats.html

21. Chornomors'kyj derzhavnyj universytet imeni Petra Mogyly, «Personal pidpryjemstva», elektronna knyga, Redakcijno-vydavnychyj centr, [Online], available at: http://lib.chmnu.edu.ua/pdf/metodser/90/8.pdf

22. Kachan, Je.P. and Shushpanov, D.G. (2009), Upravlinnja trudovymy resursamy, Jurydychna knyga, K., 358 p

23. Shvydanenko, G.O. and Fedonin, O.S. (2009), Ekonomika pidpryjemstva, navch.-metod. posibnyk, KNEU, K., 439 p.

24. Tkachuk, G.Ju. and Savic'kyj, V.V. (2014), «Evoljucija zasad upravlinnja ljuds'kym kapitalom», Problemy teorii' ta metodologii' buhgalters'kogo obliku, kontrolju i analizu, Serija Buhgalters'kyj oblik, kontrol' i analiz, Vol. 3, pp. 369377, [Online], available at: http://nbuv.gov.ua/UJRN/ptmbo_2014_3_27

25. Basjurkina, N.J. and Martologa, L.N., «Problemy efektyvnogo vykorystannja personalu na pidpryjemstvah Ukrai'ny», Market economy: modern management theory and practice, Vol. 15, Issue 2 (33), pp. 63-72, [Online], available at: http://rinek.onu.edu.ua/article/view/120438/

26. Kindrac'ka, G.I., Bilyk, M.S. and Zagorodnij, A.G. (2008), Ekonomichnyj analiz: teorija i praktyka, Magnolija 2006, L'viv, $440 \mathrm{p}$.

27. Rusinko, M.I., Sudakova, O.I. and Larchenko, G.O. (2015), «Evoljucija ponjattja "personal pidpryjemstva" ta teoretychni pidhody do jogo vyznachennja», Efektyvna ekonomika, No. 3, [Online], available at: http://nbuv.gov.ua/UJRN/Nvmgu_eim_2017_27(1)_24

28. Kibanov, A.Ja. (ed.) (2001), Upravlenie personalom organizacii: praktikum, INFRA-M, Moskva, 296 p.

29. Shegda A.V. Menedzhment : navch. posibnyk / A.V. Shegda. - Kyi'v : Znannja ; KOO, 2002. - 583 s.

30. «Osobovyj sklad», termin, [Online], available at: https://zakon.rada.gov.ua/laws/term/35169

31. Ministerstvo praci Ukrai'ny, «Instrukcija zi statystyky kil'kosti pracivnykiv», [Online], available at: https://zakon.rada.gov.ua/laws/show/z1442-05

32. Verhovna Rada Ukrai'ny, «Pro zbir ta oblik jedynogo vnesku na zagal'noobov'jazkove derzhavne social'ne strahuvannja», zakon Ukrai'ny, [Online], available at: https://zakon.rada.gov.ua/laws/show/2464-17

33. Ministerstvo praci Ukrai'ny, «Tymchasovi ta sezonni pracivnyky: pryjnjattja na robotu j oplata praci», [Online], available at: https://prohr.rabota.ua/timchasovi-ta-sezonni-pratsivniki-priynyattya-na-robotu-y-oplata-pratsi/

34. Verhovna Rada SRSR (1974), Pro umovy praci tymchasovyh robitnykiv $i$ sluzhbovciv, ukaz, vid 24 veresnja, N 31109, Prezydija Verhovnoi' Rady SRSR.

35. Verhovna Rada SRSR (1974), Pro umovy praci robitnykiv $i$ sluzhbovciv, zajnjatyh na sezonnyh robotah, ukaz, vid 24 veresnja, N 310-09, Prezydija Verhovnoi' Rady SRSR.

36. Kabinet Ministriv Ukrai'ny (1997), Spysok sezonnyh robit i sezonnyh galuzej, postanova, vid 28 bereznja, N 278.

37. Andrijchuk, V.G. (2002), Ekonomika agrarnyh pidpryjemstva, $2^{\text {nd }}$ ed., dop. i pererob., KNEU, K., 624 p., [Online], available at: https://buklib.net/books/26406/

38. Ministerstvo praci Ukrai'ny, «Shtatnyj rozpys pidpryjemstva: porjadok skladannja ta forma», [Online], available at: https://www.kadrovik01.com.ua/article/3571-qqq-17-m2-poryadok-skladannya-shtatnogo-rozpisu

39. Ministerstvo praci Ukrai'ny, «Zvit z jedynogo vnesku: jak vyznachyty shtatnu chysel'nist' pracivnykiv», [Online], available at: https://www.kadrovik.ua/novyny/zvit-z-iedinogo-vnesku-yak-viznachiti-shtatnu-chiselnist-pracivnikiv

40. Verhovna Rada Ukrai'ny, «Kodeks zakoniv pro pracju Ukrai'ny», [Online], available at: https://zakon.rada.gov.ua/laws/show/322-08

41. Verhovna Rada Ukrai'ny, «Gospodars'kyj kodeks Ukrai'ny», [Online], available at: https://zakon.rada.gov.ua/laws/show/436-15

42. Ministerstvo praci Ukrai'ny (2016), «Robota za sumisnyctvom: vid pryjnjattja do zvil'nennja», [Online], available at: https://www.kadrovik01.com.ua/article/105-qqq-16-m5-19-05-2016-robota-za-sumsnitstvom-vd-priynyattya-dozvlnennya

43. Minpraci Ukrai'ny, Min'just Ukrai'ny, Minfin Ukrai'ny (1993), Polozhennja pro umovy roboty za sumisnyctvom pracivnykiv derzhavnyh pidpryjemstv, ustanov i organizacij, nakaz, vid 28 chervnja, N 43.

44. Verhovna Rada Ukrai'ny, «Cyvil'nyj Kodeks Ukrai'ny», [Online], available at: https://zakon.rada.gov.ua/laws/show/435-15

Смачило Валентина Володимирівна - кандидат економічних наук, доцент, професор кафедри економіки Харківського національного університету будівництва та архітектури.

Наукові інтереси:

управління персоналом, економіка праці та підприємства, соціальна відповідальність та підприємництво.

Orcid.org/0000-0002-6153-1564

Наливайко Тарас Любомирович - здобувач ступеню «доктор філософії» за спеціальністю 051 «Економіка» кафедри економіки Харківського національного університету будівництва та архітектури

Orcid.org/0000-0003-2149-7370

Наукові інтереси:

- управління персоналом, економіка праці та підприємства. 